\title{
Protein Resistance of Titanium Oxide Surfaces Modified by Biologically Inspired mPEG-DOPA
}

\author{
Jeffrey L. Dalsin, ${ }^{\dagger}$ Samuele Tosatti, ${ }^{\ddagger}$ Janos Vörös, ${ }^{\ddagger}$ Marcus Textor, ${ }^{\ddagger}$ Phillip B. Messersmith ${ }^{\dagger} *$ \\ ${ }^{\dagger}$ Biomedical Engineering Department, Northwestern University, \\ 2145 Sheridan Road, Evanston, IL USA \\ ${ }^{\ddagger}$ Laboratory for Surface Science and Technology, \\ Swiss Federal Institute of Technology (ETH), Zürich, Switzerland
}

Supporting Information

\section{Mass Spectra}

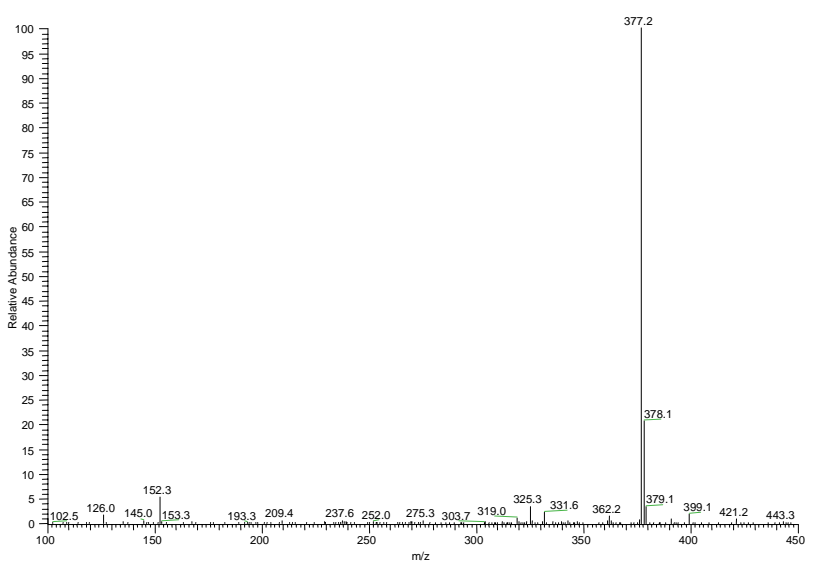

Figure S1. ESI-MS spectrum of $\mathbf{D O P A}_{2}$. Determined molecular weight $\mathrm{m} / \mathrm{z} \quad 377.2 \quad(\mathrm{M}+1) \quad$ (calculated monoisotopic molecular weight 377.13).

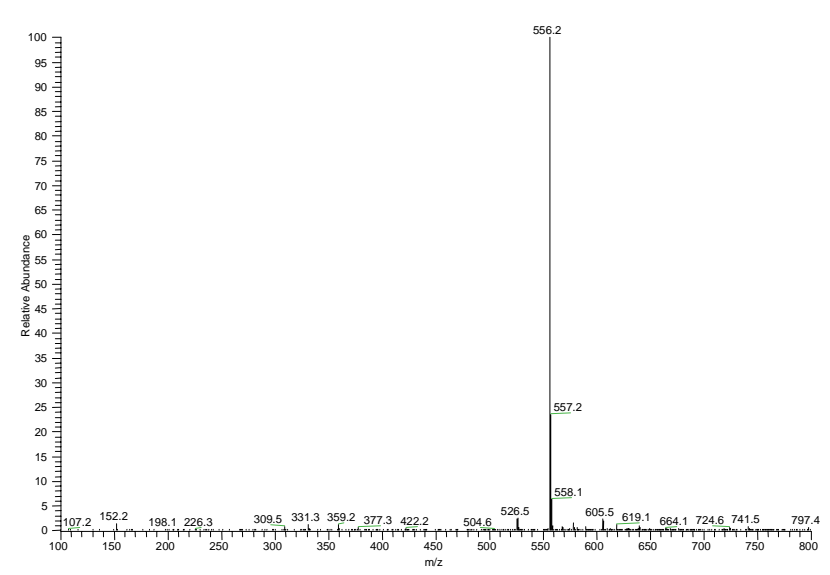

Figure S2. ESI-MS spectrum of $\mathbf{D O P A}_{3}$. Determined molecular weight $\mathrm{m} / \mathrm{z} \quad 556.2 \quad(\mathrm{M}+1) \quad$ (calculated monoisotopic molecular weight 556.19).

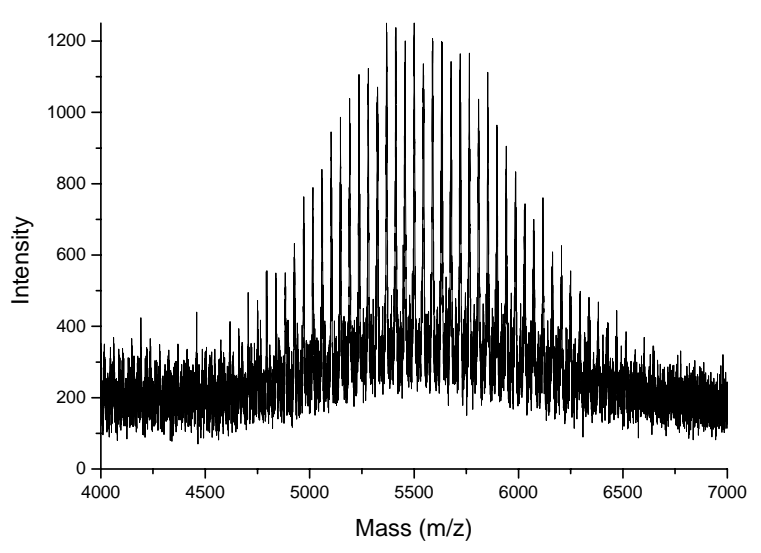

Figure S3. MALDI-MS spectrum of mPEG-DOPA.

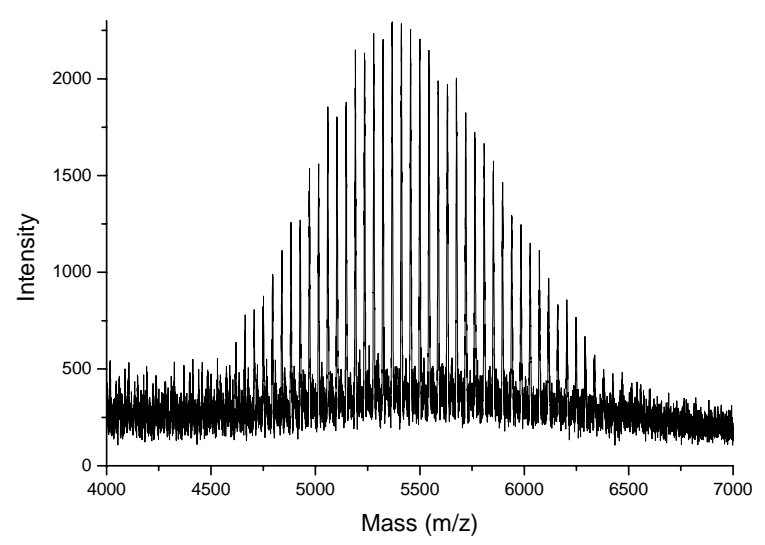

Figure S4. MALDI-MS spectrum of mPEG-DOPA $_{2}$.

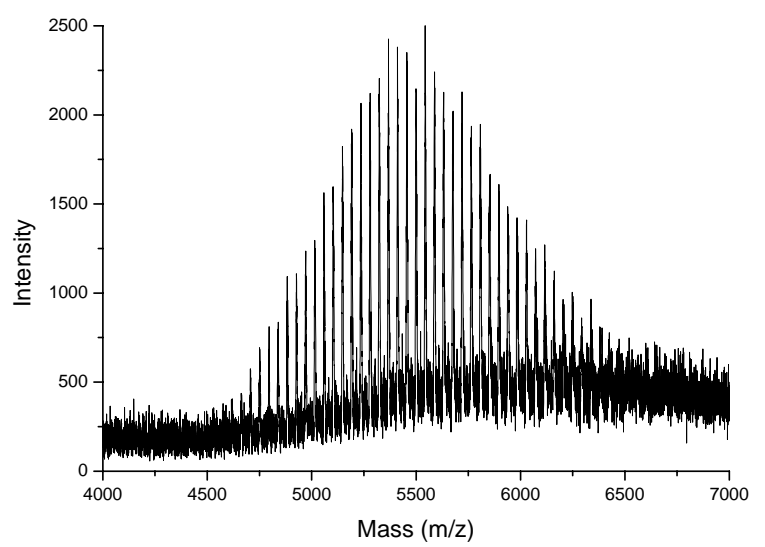

Figure S5. MALDI-MS spectrum of mPEG-DOPA $_{3}$. 